\title{
MANAJEMEN PROSES SEBAGAI PERBAIAKAN PENDIDIKAN YANG BERKUALITAS
}

\begin{abstract}
Abstrak
Suatu penelitian ini menggambarkan dan menjelaskan mengenai tentang prose atau yang di sebut dengan manajemen proses yang di dalam penelitian ini terdapat banyak urayan tau pembahasan dan pemecahan masalah yang membahas tentang apa yang di maksud dengan manajemen proses dan perbaikan prose untuk pendidikan yang berkualitas, hasil penelitian ini menggambarkan tentang;1. Pengertian proses dan manajemen proses,2. Komponen penting dalam manajemen proses,3. Langkahlangkah perbaikan proses untuk memperbaiki suatu kualitas Pendidikan,4. .Memecahkan suatu permasalahn dalam manajemen proses yang terjadi di lingkuan,5. Mengembangkan dan menguji ide-ide,6. Mengimpelementasiakan suatu Penerapan di dalam suatu manajemen prose.
\end{abstract}

1.Pendahuluan

\subsection{Latar Belakang}

Dengan seiringnya berjalanya waktu dan berkembangnya zaman yang saat ini semakin maju dan berpengaruh besar kepada suatu pendidikan di lingkungan kita,di dalam pendidikan ada beberapa masalah mengalami suatu perubahan dari segi masukan,dan juga pengeluaran proses (outcome).

Dalam penelitian ini kami memfokuskan kepada suatu proses sebagai peningkatan pendidikan yang berada di Negara kita agar kostumer merasa cukup terhadap produk yang telah ada Sehingga suatu hasil dari semua instansi sehingga kedepana harus ditingkatkan karya dan produk-produk yang berkualitas,Dalam suatu proses biasanya lebih difokuskan maka suatu output pendidikan akan mempunyai berkualitas yang bik, dan akan ada banyak perubahan dari pada lembag pendidikan di negara sekitar kita.

\section{Pengertian proses dan manajemen proses}

Pada umumnya, suatu usaha atau produk itu diproduksi dengan baik adalah untuk memuaskan suatu pelanggan dalam suatu lembaga atau perusahaan, sehingga proses suatu pekerjan harus ditingkatkan performansinya secara terus-menerus, 
karena seiring berkembangnya suatu zamanyang telah berbeda dan sudah banyak perubahan selera dan kebutuhan pelanggan selalu berubah-ubah dan berbeda -beda yang di sebut dengan relative.

Suatu proses adalah salah satu integrasi sekuensial atau yang biasa di sebut (berurutan) dari salah satu orang,dan juga material,dan ada juga metode-metode yang ada, dan mesin atau alat bantu peralatan dalam suatu lingkungan yang bertujuan untuk menghasilkan suatu karya atau nilai tambah yang di sebut dengan output untuk para pelanggan,Ada pula yang di maksut dengan pengertian manajemen proses ini adalah proses pengelolahan yang di sebut dengan integrasi sekuensial (berurutan) dari salah satu perorangan orang, material,dan suatu metode, dan mesin atau peralatan di dalam suatu ruang lingkup lembag supaya mengahsilkan nilai tambah sebagai output untuk semua pelanggan, Dalam hal ini terdapat beberapa pihak yang terlibat dalam pengoperasi dan perbaikan proses, antara lain:

> Pelanggan adalah seseorang yang dapat mengoprasiakan output secara berlangsungan sebagai input dalam suatu proses pekerjaan mereka.

Kelompok kerja adalah dua orang atau lebih yang mempunyai kewajiaban dalam suatu kelompok atau lebih yang di dalamnya terdapat beberapa orang yang mengerjakan suatu proses bertujuan untuk mendapatkan hasil output yang diinginkan oleh konsumen atau pelanggan.

> Pemasok adalah suatu konsumen yang memberikan input terhadap proses pekerjaan. Seseorang yang mempunyai wewenang kerja dalam proses pada kenyataanya ialah merupakan pelanggan atau pemasok.

$>$ Pemilik adalah orang yang mempunyai wewenang untuk beroperasi dan menjaga dari proses dan untuk perbaikan prose itu sendiri.

Sudah kita ketahui, bahwasanya pengertian suatu pelanggan ialah orang yang mendefinisikan suatu output yang diinginkan dari semuah proses. Di pandang dari sisi kejauhanada beberapa perolehan melalui 2 kategori info atau berita yang mengalir dari pelanggan ke kelompok kerja, antara lain sebagai berikut:

Kebutuhan seorang pelanggan yang merupakan suatu peran penting yang telah diinginkan,dan dibutuhkan ataupun yang diharapkan oleh seorang pelanggan. 
Umpan balik adalah suatu permasalahn tentang baik atau buruknya suatu output yang telah diserahkan dalam perbandingannya dan perbedaan dengan ekspektasi pelanggan

3. Komponen dalam salah satu manajemen proses

Suatu program atau konsep dari manjemen proses ini berkaitan dengan perbaikan kualitas,ada seseorang pakar yang menafsirkan komponen penting dalam proses manajemen ,Gabriel Pall menggambarkan ada 6 gambaran yang sangat penting untuk proses manajemen, antara lain:

Kepemilikan (ownership) menugaskan mempunyai hak atau tanggung jawab untuk suatu desain, operasi, dan perbaikan proses.

> Perencanaan (planning) menetapkan suatu pendekatan yang sudah terstruktur dan tersusun rapi untuk mengerti, dan mengidentifikasikan, dan mendokumentasikan semua komponen utama dalam proses dan hubungan antar-komponen utama dan komponen lainya.

$>$ Pengendalian (control) ini menjamin atas efektivitas dan ke efisien atas suatu program atau suatu lembaga, dimana semua output dalam perbaiakn proses diperkirakan dan konsistennya dengan ekspektasi pelanggan.

$>$ Pengukuran (measurement) memetakan atau menggambarkan suatu performansi atribut terhadap kebutuhan pelanggan dan menetapkan kriteria untuk akurasi, presisi, dan frekuensi perolehan dalam suatu data yang telah ada.

$>$ Perbaikan atau peningkatan (improvement) meningkatkan efektifitas dari suatu proses terkecil hingga proses terbesar melalui perbaikan-perbaikan yang diidentifikasi secara tetap.

> Optimisasi (optimization) meningkatkan produk atau karya yang harus di efisienkan dan di produktivitaskan melalui perubahan yang diidentifikasi secara tetap.

Beberapa hal komponan di atas merupakan landasan untuk keberhasilan suatu yang di nilai dari beberapa sudut manajemen dari suatu proses apa saja. Komponenkomponen tersebut dibutuhkan untuk memperjelas proses kerja yang menghasilkan dan menyerahkan produk yang berkualitas ke pelanggan,oleh hal itu untuk proses yang menspesifikasikan kebutuhan dalam mencapai suatu kebutuhan dan kepuasan 
parapelanggan,pemasok, dan untuk proses yang mendukung atas pekerja dalam pekerjaan mereka.

Setiap organisasi itu dapat mengidentifikasikan beberapa dalam proses kunci dan cara pengelolaan yang mempengaruhi keberhasilannya, Kita bisa dapat menggunakan enam pertanyaan berikut ini untuk membantu dalam mengidentifikasi proses kunci yang memiliki dampak terbesar pada pelanggan, yaitu:

Suatu produk apa yang sering diterpentingkan bagi pelanggan?

$>$ Proses apa saja yang menghasilkan produk atau hasil dari suatu program dan system suatu manajemen proses ini?

$>$ Komponen atau faktor kunci apa yang berpengaruh atau mempengaruhi suatu tindakan dalam organisasi, dan proses apa yang mengkonversi atau mengubah rangsangan ini menjadi output?

$>$ Proses seperti apa yang memiliki visibility atau pengaruh tertinggi dengan pelanggan?

> Proses manakah yang sangat berpengaruhdan memiliki dampak terbesar terhadap standar performansi yang dikendalikan oleh pelanggan?

> Berdasarkan data yang telah ada performansinya, proses mana yang memiliki potensi terbesar untuk perbaikan?

4. Langkah-langkah perbaikan proses untuk memperbaiki suatu kualitas Pendidikan.

Di dalam suatu perbaikan suatu proses ada beberapa langkah yang dilakukan dengan beberapa usaha tau langkah-langkah yang ada dalam suatu langkah proses perbaiakan , antara lain seperti berikut ini:

1. Mendefinisikan tentang masalah proses

Mendefinisikan model perbaikan proses ini biasanya dimulai dari sudut penetapan yang telah terspesifikasi oleh sistem yang telah terlibat, agar dalam suatu usaha-usaha dalam terfokus pada proses bukan pada output. Ada beberapa aktivitas spesifik yang telah ada di bawah ini antara lain:

Mengidentifikasi output.

> Mengidentifikasi pelanggan. 
$>$ Definisi kebutuhan suatu pelanggan.

$>$ Identifikasi proses yang menghasilkan

$>$ Identifikasi pemilik suatu proses

\section{Identifikasi suatu dokumen proses}

Suatu program diagram alir ini ialah merupakan alat yang sudah umum dipakai untuk menggambarkan proses,untuk mempermudah suatu pengamatan proses ialah dengan Pembuatan suatu diagram aliran ini biasanya dari suatu proses maka salah satu solusi demi melakukan 4 aktivitas perbaikan berikut:

$\checkmark$ Mengidentifikasi salah satu peserta dalam proses yang bertujuan agar lebih mudahhnya berjalana sebuah proses sistem, berdasarkan nama, posisi atau organisasi.

$\checkmark$ Memberikan suatu arahan tentang pemahaman umum mengenai bagai mana kita bisa memahami langkah-langkah dan peran suatu individu dari mereka.

$\checkmark$ Mengidentifikasi suatu ke efisiensi, pemborosan, dan langkahlangkah redundant yang kita sebut dengan (berlebihan atau tidak perlu) dalam proses

$\checkmark$ Mempromosikan suatu kerangka pekerja untuk mendefinisikan pengukuran salah satu proses.

Dalam suatu pengukuran performansi yang sedang berjalan atau beroperasi, Mengukur performansi harus diidentifikasikan dan dievaluasi dalam konteks ekspektasi seorang pelanggan. Dengan bahasa lain setiap ukuran performansi yang selalu digunakan harus mengacu pada ekspektasi pelanggan.Suatu dasar biasanya pengukuran performansi biasanya dilakukan dengan tiga tingkat, yaitu: proses, output, outcome. Mengukur output mendefinisikan features spesifik, nilai-nilai, dan atribut dari setiap produk yang dapat diuji dari dua sisi, antara lain sebagai berikut:

- Berkaitan dengan karakteristik output yang diinginkan oleh pelanggan (kebutuhan pelanggan)

- Secara aktual karakteristik outputdi serahakan kepada proses. 
Suatu kebutuhan seorang pelanggan sering kali di butuhkan dan di bilang oleh pakar ialah suara pelanggan,Suatu kapabilitas proses sering disebut sebagai salah satu suara dari proses, outcome mendefinisikan dampak absolut dari proses dan tergantung pada kepuasan pelanggan,Dengan demikian suatu kepuasaan pelanggan merupakan ukuran kunci dan outcome.

Suatu langkah dalam model perbaikan proses ini di mulai dengan perencanaan dan dan pengimplementasikan perbaiakn-perbaikan yang di indifikasikan untuk mengukur dan mengevaluasi dari proses dari yang di perbaiki sebagai informasi yang dip roses selanjutnya akan di jadikan sebagai umpan baik untuk melaksanakan perbaikan proses selanjutnya.

5. Meneliti suatu permasalahan dalam manajemen proses yang terjadi di lingkuan

Keterbatasan data menimbulkan kesulitan untuk memahami suatu sistem yang berjalan seperti semula sehingga harapan tidak sesuai dengan yang diharapkan. Masalah adalah suatu penyimpangan yang terjadi antara formansi yang diharapkan (sasaran) dan performansi actual (hasil actual). Contoh pernyataan masalah: "Ada beberapa pernyataan mesin produksi M kurang mampu memproduksi lebih 70\% dari desain kapasitasnya". Bagai mana cara memahami suatu masalah terjadi, ialah proses kea rah perbaikan proses efektif dan efisien, kita lihat tabel berikut;

\begin{tabular}{|l|l|l|l|}
\hline Tingkat & Observasi & tindakan & hasil \\
\hline Gejala & Aki mati & Di ganti & Sudah lancer \\
\hline & & & \\
Penyebab & Lampu depan mati & Di perbaiki & Lancer \\
\hline & & & \\
Akar penyebab & $\begin{array}{l}\text { Perawatan rutin tidak } \\
\text { terlaksana }\end{array}$ & Servis rutin & $\begin{array}{l}\text { Sudah } \\
\text { terkendalikan }\end{array}$ \\
\hline
\end{tabular}

6. Mengembangkan dan menguji ide-ide 
Ada empat langkah yang dulu membangun kerangka dasar untuk memahami arti kritis dari manajemen proses, dengan cara mendalami kunci dari sebuah proses, mengukur bagaimana caranya baik atau jelek prose beroperasi, dan memahami mengapa proses itu beroperasi dengan cara sendirinya sehingga menimbulkan masalah

Keempat gambaran di atas adalah salah satu langkah meringankan kita untuk menemukan masalah-masalh dari masalah utama. Ide-ide sebagai perbaikan proses bisa kita temui pada masalah yang telah ada. Agar suatu ide-ide yang telah di kumpulkan untuk perbaikan proses itu efektif, Ide-ide itu perlu diuji dan di evaluasi terlebih dahulu sebelum diimplementasikan.Pengalaman-pengalalam dari ide-ide itu bisa membantu menghindarkan kegagalan ketika ide-ide tersebut diimplementasikan dalam proses. Dengan demikian langkah ke-5 ini juga cara mengembangkan dan menguji ide-ide untuk perbaikan proses melalui suatu eksperimentasi,

7. Mengimpelementasiakan suatu Penerapan di dalam suatu manajemen prose.

Proses merupakan salah satu pekerjaan yang dilakukan untuk menghasilkan sebuah barang atau jasa yang akan di paparkan atau di gambarkan pada kostumer adalah bertujuan memahami apa yang dibutuhkan pada sisi masukan bertujuan untuk menjalankan sebuah proses.opini tersebut dapat berupa materi, informasi, bimbingan, regulasi atau tindakan. Sangat penting bagaimana memahami proses anda member tambahan nilai untuk masukan yang anda terima sehingga anda dapat menghasilkan keluaran yang bermutu untuk keluaran anda.

$$
\text { Masukan + Proses Nilai Tambah = Mutu Keluaran }
$$

pemahaman di atas dapat kita lihat pada penerapan manajemen siswa, ketika suatu saat sampai dalam penerimaan siswa baruatau kita sering menyebut dengan(PSB) di sekolah para guru dan kepala sekolah beserta karyawan berusaha menyeleksi calon siswa baru akan meneruskan di lembaga yang berkualitas, dengan harapan di saat proses pembelajaran berjalan lancar dan menghasilkan kompetensi atau karya lulusan yang unggul dan berkarya. 
Di dalam suatu pengimplememntasian belajar mengajar siswa diarahkan kepada hal yang baik baik, jika terjadi kesalahan harus diberi sanksi baik berupa teguran, peringatan tertulis, dibimbing oleh guru BK dan lain-lain. Salah satu tujuan layanan Bimbingan dan konseling ialah bertujuan mengenalakn yang jelas mengenai dirinya, situasi lingkungan dan mampu mengatasi kesulitan-kesulitan yang berkaitan dengan pemahaman dirinya, sehingga proggram suatu bimbingan dan konseling sangat diperlukan di dalam sekolah. Dengan berjalanya suatu proses yang sedemikian rupa di oprasikan, Semua kostumer diharapkan bisa puas dengan suatu hasil yang diperoleh, yaitu menghasilkan lulusan yang bermutu, dan bersertifikat tinggi.

\section{Penutup}

Di mulai dari penjalasa yang sudah di uraikan di atas bisa di simpulakan bahwasanya Proses ialah salah satu usaha demi mencapai sesuatu yang ingin dicapai dari orang, material, metode,

Dan mesin atau peralatan dalam suatu lingkungan agar bisa mengahsilkan nilai atau karya tambah output untuk pelanggan. Sedangkan manajemen proses dapat kita artikan sebagi proses pengelolahan integrasi sekuensial (berurutan) dari orang, material, metode, dan mesin atau peralatan dalam suatu lingkungan guna mengahsilkan nilai tambah output untuk pelanggan.

Di dalam perbaikan proses itu terdapat 4 hal yang terlibat, yaitu: pelanggan, kelompok kerja, pemasok dan pemilik. Selain itu, ada juga 4 komponen yang penting dalam manajemen proses, yaitu: kepemilikian, perencanaan, pengendalian, pengukuran, perbaikan dan optimisasi.

Ada sebagaian langkah-langkah perbaikan prose ini meliputi berikut: definisi masalah,Identifikasi dan dokumentasi mengenai proses, mengembangkan dan menguji ide-ide serta implementasi solusi dan evaluasi. Salah satu contoh penerapan proses ialah bisa diterapkan dalam manajemen siswa. 


\section{DAFTAR PUSTAKA}

Nasution, Nur. Manajemen Mutu Terpadu (Management Total Quality).(Bogor: Ghalia Indonesia, 2015).

Gaspersz, Vincent. Total Quality Management. (Jakarta: Gramedia Pustaka Utama, 2008). Manajemen Pendidikan

Mundiri, A., Laili, I. N., Hasanah, N., \& Humairoh. (2018). Pengembangan Media Pembelajaran Pendidikan Agama Islam; Konsepsi, Konvergensi, dan Implementasi. Probolinggo: Pustaka Nurja.

Mundiri, A. (2015). KOMITMEN ORGANISASIONAL SUMBER DAYA MANUSIA DALAM MENINGKATKAN MUTU PENDIDIKAN PESANTREN. Pedagogik, 3(1), 88-105.

Mundiri, A. (2016). THE LEADERSHIP OF HEADMASTER IN BUILDING A WORK CULTURE BASED ON PESANTREN. In International Conference on Education and Training (pp. 1-7). Malang: Faculty of Education State University of Malang. 